\title{
ogopaedica
ogziensia
}

$\operatorname{Nr} 3$ (2019)

DOl: http://dx.doi.org/10.18778/2544-7238.03.07

Katarzyna Haniszewska, Monika Kaźmierczak*

\section{Higiena głosu artystów scenicznych Doniesienia z badań}

Vocal hygiene in stage artists. Research reports

\begin{abstract}
Słowa kluczowe: głos, higiena głosu, zaburzenia głosu, amatorzy i profesjonalni użytkownicy głosu, aktorzy
Keywords: voice, vocal hygiene, voice disorders, amateur and professional voice users, actors
\end{abstract}

\section{Wprowadzenie}

Możliwość tworzenia głosu w celu komunikacji z innymi za pomocą mowy jest jednym z podstawowych przywilejów gatunku homo sapiens. Do wytworzenia komunikatu werbalnego człowiek potrzebuje wielu współpracujących ze sobą mechanizmów i narządów. Na etapie dźwiękowej realizacji wypowiedzi są to aparaty: fonacyjny, artykulacyjny i oddechowy, a także ośrodki oraz drogi nerwowe odpowiedzialne za przekazanie bodźca i wykonanie zaplanowanych czynności. Ich prawidłowe, zsynchronizowane działanie umożliwia człowiekowi tworzenie głosu, bez którego nie mógłby komunikować się werbalnie $\mathrm{z}$ innymi. Zjawisko tworzenia głosu jest przedmiotem zainteresowania wielu dziedzin, w tym foniatrii, psychologii czy logopedii - zarówno od strony biologicznej (fizjologii, anatomii i patologii narządu głosu), psychologicznej (wpływu emocji na powstawanie głosu i jego zaburzeń), jak i artystycznej (cech jakościowych głosu oraz higieny głosu) [Kamińska, Milewski, 2016] u osób używających go zawodowo lub hobbystycznie.

Wśród aktorów teatralnych (z dyplomem szkoły artystycznej lub amatorów), dla których głos pozostaje jednym z podstawowych środków wyrazu, szczególnie istotna jest wysoka świadomość dotycząca jego higieny, a obserwacje dowodzą, że objawy dysfonii są niejednokrotnie ignorowane przez osoby zawodowo pracujące głosem

\footnotetext{
* Uniwersytet Łódzki, Wydział Filologiczny, Instytut Filologii Polskiej i Logopedii, Zakład Dialektologii Polskiej i Logopedii, ul. Pomorska 171/173, 90-236 Łódź, e-mail: monika.kazmierczak@uni. lodz.pl, https://orcid.org/0000-0003-4396-3627
} 
[Walencik-Topiłko, 2012]. Przestrzeganie podstawowych zasad higieny głosu warunkuje dobrą jakość mówienia na co dzień oraz podczas wystąpień scenicznych ${ }^{1}$, szczególnie że aktorstwo należy do grupy zawodów wymagających specjalnej jakości głosu (według podziału zawodów w zależności od wymagań stawianych narządowi głosu, dokonanego przez ekspertów Unii Europejskiej Foniatrów [Pruszewicz, 1992]). Aktor potrzebuje czegoś więcej niż komunikowania się na poziomie potrzeb - pragnie przekazywać innym swoje myśli, odczucia, przeżycia i emocje, dzielić się swoją wizją świata i przekonaniami, a zaburzenia głosu mogą to znacznie utrudnić 2 , powodując dyskomfort podczas mówienia lub śpiewania. Wiążą się bowiem ze znaczącym obniżeniem walorów estetycznych i jakości pracy artystycznej, niekiedy do tego stopnia, że aktor nie jest w stanie wykonywać jej wystarczająco dobrze i w związku z tym istnieje potrzeba zastąpienia go przez dublera.

\section{Higiena głosu}

Przedmiotem zainteresowania higieny jako nauki jest określenie wpływu otoczenia na zdrowie człowieka oraz ludzkie reakcje i postawy względem tego wpływu. Higiena głosu służy w głównej mierze eliminacji nieprawidłowych nawyków, podnoszeniu poziomu wiedzy oraz świadomości dotyczącej budowy i funkcjonowania narządu głosu, zapobiegania chorobom czy też wdrażania działań profilaktycznych i metod rehabilitacji [Rokitiańska, Laskowska, 2003]. Zapobieganie problemom głosowym polega w dużej mierze na przestrzeganiu zasad higieny głosu, która, analizując warunki życia człowieka, identyfikuje czynniki (nie)korzystne dla narządu głosu oraz wskazuje możliwe sposoby unikania tych szkodzących człowiekowi lub przeciwdziałania im [Kubiak, Wiskirska-Woźnica, Demenko, 2006]. Co istotne, higiena głosu może być rozpatrywana w ramach profilaktyki zaburzeń głosu lub jako jedna z technik zapobiegających pogłębianiu problemów z głosem - jako składowa kompleksowego programu rehabilitacji [Behlau, Oliveira, 2009].

Zapobieganie chorobom oraz poprawa całościowego dobrostanu człowieka są szczególnie ważne dla osób zawodowo posługujących się głosem, dla których jest

1 Głos eufoniczny jest czysty, dźwięczny i nośny, a jego brzmienie nie ulega zmianie po wysiłku [Pawłowski, 2005; Cieszyńska, 2016]. Wśród aktorów objawy zaburzenia głosu (np. chrypka) mogą być jednak poczytywane nie za patologiczne, a za pożądane, wyróżniające głos jednostki w środowisku. 2 Skutkiem zaburzeń fonacji jest obniżenie jakości głosu. Jako objawy pojawiają się: chrypka, szum, zmniejszenie dźwięczności, zmatowienie głosu, nieprawidłowe nastawienie, bezgłos, dwugłos, duszność lub załamywanie głosu. Innymi objawami mogą być dolegliwości ze strony narządu głosu, takie jak ból, uczucie ściskania, pieczenia czy drapania w okolicy gardła i krtani, uczucie zalegania, przeszkody, „kluski w gardle” lub gałki w obrębie szyi (globus), konieczność odkrztuszania, odchrząkiwania, suchość jamy ustnej i gardła, bóle mięśni szyi czy karku spowodowane zwiększonym ich napięciem, trudności w oddychaniu (duszność lub zmniejszona pojemność oddechowa płuc - uczucie „braku powietrza") [Obrębowski, 2008; Śliwińska-Kowalska, Niebudek-Bogusz, 2009; Cieszyńska, 2016]. 
on jednym z podstawowych narzędzi pracy. Wielu autorów podejmuje temat higieny głosu [m.in. Kubiak, Wiskirska-Woźnica, Demenko, 2006; Tarasiewicz, 2006; Śliwińska-Kowalska, Niebudek-Bogusz, 2009; Binkuńska, 2012; Kisiel, 2012; Walencik-Topiłko, 2012) i podaje podobne zalecenia oraz zasady3.

Podstawową kwestią, na którą trenerzy głosu, logopedzi i lekarze specjaliści zwracają uwagę, jest wykonywanie kontrolnych badań lekarskich (laryngologicznych lub foniatrycznych), szczególnie gdy planuje się wybór zawodu stawiającego wysokie wymagania narządowi głosu lub gdy już wykonuje się taki zawód. Ważne, aby na badania zgłaszać się regularnie, w celu wykrycia ewentualnych chorób w jak najwcześniejszym stadium rozwoju, gdy jeszcze nie dają nasilonych objawów. Niezwykle istotne jest też zapobieganie infekcjom górnych dróg oddechowych, gardła i krtani oraz jak najszybsze podejmowanie skutecznego leczenia w przypadku ich wystąpienia, gdyż jest to zespół chorób groźnych, jeśli dojdzie do zaniedbań [Walencik-Topiłko, 2012]. W czasie trwania infekcji należy zachować spokój głosowy, nie narażać narządu głosu na przeciążenia, a w razie potrzeby zwolnić się z obowiązków zawodowych.

Duże znaczenie dla jakości głosu ma dieta i higiena snu. Nie powinno się jeść zbyt pikantnych potraw oraz narażać narządu głosu na bardzo wysokie lub bardzo niskie temperatury (spożywać pokarmy i napoje niezbyt zimne lub gorące, szczególnie na krótko przed wysiłkiem głosowym). Bezwzględnie nie wolno palić tytoniu, dobrze jest znacznie ograniczyć spożycie alkoholu, szczególnie wysokoprocentowego. Zaleca się natomiast zwiększenie spożycia wody, najlepiej pod postacią niegazowanej wody mineralnej lub niskosłodzonych soków owocowych. Powinno się ograniczyć mocną kawę lub herbatę, gdyż oba te napoje wysuszają błonę śluzową. Ostatni lekki posiłek, zjadany minimum trzy godziny przed położeniem się do łóżka, warunkuje dobrą jakość snu i efektywność nocnej regeneracji. Regularny oraz zdrowy tryb życia w istotny sposób wpływa na funkcjonowanie organizmu, a tym samym na jakość komunikacji ustnej.

Na pracę głosem mają wpływ również czynniki zewnętrzne, takie jak warunki w pomieszczeniu, w którym wykonuje się tę pracę. Temperaturę powietrza, w zależności od pory roku oraz podejmowanej aktywności, powinno się utrzymywać w przedziale $15-26^{\circ} \mathrm{C}$, przy względnej wilgotności około $40-70 \%$ [Gładyszewska-Fiedoruk, 2010]. Dla artystów, podejmujących na scenie dużą aktywność fizyczną wartości te powinny być utrzymywane zimą w przedziale $15-18^{\circ} \mathrm{C}$, przy względnej wilgotności powietrza $40-60 \%$, a latem $18-21^{\circ} \mathrm{C}$, przy wilgotności $40-70 \%$. Optymalne warunki - około $18-20^{\circ} \mathrm{C}$, przy względnej wilgotności $45-50 \%$ - dobrze jest wprowadzić w sypialni, gdyż w czasie snu regeneruje się cały organizm, w tym śluzówka krtani.

3 Na podstawie informacji zaczerpniętych z literatury przedmiotu opracowano Zasady higieny głosu (załącznik 1), które zostały wykorzystane w badaniach własnych. 
Należy również unikać nadmiernego wysiłku głosowego, gdy jest się w złym stanie emocjonalnym, ponieważ wówczas narząd głosu jest mniej odporny na przeciążenia. Dbanie o głos wiąże się też z opanowaniem prawidłowej techniki jego emisji, która zależy od sposobu oddychania, fonacji oraz właściwej artykulacji. Dobrze jest rozpocząć naukę emisji głosu odpowiednio wcześniej przed podjęciem pracy głosem, gdyż proces nabywania i utrwalania nowych nawyków wymaga zaangażowania i systematycznej pracy przez co najmniej kilka miesięcy. Podczas ćwiczeń należy zwrócić szczególną uwagę na wypracowanie prawidłowej postawy ciała, pozwalającej skutecznie realizować każdą aktywność ruchową [szerzej na temat postawy ciała patrz Błaszczyk, 1993].

\section{Metodologia badań własnych}

Głównym przedmiotem prowadzonych badań była świadomość 4 i postawy ${ }^{5}$ artystów scenicznych (aktorów zawodowych - grupa „Z” i amatorów - grupa „A”) względem higieny głosu oraz postrzegania własnego głosu: jego możliwości, ograniczeń czy zmian, jakim podlega podczas wysiłku. Przeprowadzone analizy miały na celu ocenę świadomości i postaw w tym zakresie przed zapoznaniem respondentów z zasadami i zaleceniami dotyczącymi higieny głosu oraz po trzech miesiącach od ich przekazania każdej z grup. Istotna była odpowiedź na pytanie, czy po otrzymaniu zasad ankietowani zapoznali się z treścią dokumentu, co sądzą o własnej higienie głosu w kontekście poznanych zasad, czy któreś udało im się zastosować oraz czy zauważyli jakieś zmiany w brzmieniu swojego głosu lub w komforcie pracy. Wyniki badań ankietowych skonfrontowano z obserwacją i oceną percepcyjną głosu przeprowadzoną przez badacza.

Na postawie wyznaczonych celów i przedmiotu badań sformułowano następujące problemy badawcze:

1. Jaka jest świadomość aktorów (zawodowych i amatorów) w zakresie higieny głosu?

2. Jakie deklarują postawy względem zasad higieny głosu i jakości własnego głosu?

3. Czy, a jeśli tak, to jakie są różnice w świadomości na temat higieny głosu między aktorami profesjonalnymi i amatorami sztuki aktorskiej oraz w stosowaniu się do poznanych zasad między przedstawicielami obu grup?

4. W jaki sposób aktorzy (zawodowi i amatorzy) dbają o swój głos?

\footnotetext{
4 Tu w znaczeniu: 'zdawanie sobie z czegoś sprawy'.

5 Postawa człowieka wobec jakiegoś przedmiotu (fizycznego lub społecznego) jest definiowana jako dyspozycje do zachowania się w określony sposób, co jest związane $\mathrm{z}$ jego emocjonalnym lub krytycznym stosunkiem wobec tego przedmiotu oraz odnoszącymi się do niego elementami poznawczymi [por. Nowak, 1973; Marody, 1976].
} 
5. Czy artyści sceniczni (zawodowi i amatorzy) są świadomi konieczności poszerzania wiedzy z zakresu prawidłowego użytkowania głosu i dbania o niego? Czy w ogóle czują taką potrzebę?

6. Czy po zapoznaniu się z zasadami higieny głosu u aktorów (zawodowych i amatorów) wystąpiła zmiana zachowania wobec higieny głosu oraz poprawiła się jakość głosu badanych?

Można założyć, że duża troska o głos artystów scenicznych występuje niezależnie od tego, czy aktor jest profesjonalistą, czy amatorem. Jednak to aktorzy profesjonalni powinni lepiej orientować się w zasadach higieny głosu, jak również przejawiać większą świadomość własnego głosu niż osoby, które nie ukończyły wyższych studiów na wydziałach aktorskich $\mathrm{i}$ - zgodnie z deklaracją w metryczce ankiety - nie przeszły wieloletniego treningu. Można przypuszczać, że aktorzy czują potrzebę poszerzania wiedzy na temat higieny głosu, a nowe informacje wpłyną na zmianę postaw przynajmniej niektórych badanych, co w efekcie poprawi jakość ich głosu.

Podczas prowadzonych badań wykorzystano:

1) internetowe badanie ankietowe - w pierwszym etapie badania każdy respondent samodzielnie wypełniał przesłany mu autorski kwestionariusz pierwszy (załącznik 2), a wypełnioną ankietę odsyłał osobie badającej (przez internet); kwestionariusz drugi (załącznik 3) został przygotowany tak, aby ponownie określić stan higieny głosu badanych (wiele pytań powtórzonych z pierwszego kwestionariusza), jak również subiektywną ocenę swojego głosu (przez umieszczenie pytania otwartego, umożliwiającego podzielenie się opinią i odczuciami względem dbałości o swój głos);

2) bezpośrednią ukierunkowaną obserwację podczas spontanicznego mówienia badanych z uwzględnieniem postawy ciała, oddychania, koordynacji oddechowo-fonacyjno-artykulacyjnej (o-f-a), motoryki artykulacyjnej, czynności rezonatorów, natężenia i wysokości głosu, tempa mówienia; dyspozycje do obserwacji są zgodne z Kartą badania logopedycznego Marty Wysockiej, Anny Skoczylas, Agaty Szkiełkowskiej i Marzeny Mularzuk [2009]6;

3) ocenę percepcyjną głosu w skali GRBAS - jest to pięcioparametrowa skala odsłuchowa, pozwalająca określić stopień nasilenia następujących objawów zaburzeń głosu: G (ang. grade of hoarseness) - stopień chrypki, R (ang. roughness) - szorstkość głosu, B (ang. breathiness) - głos chuchający, A (ang. asthenic) - głos słaby, asteniczny, S (ang. strained) - głos napięty, hyperfunkcjonalny; każdy z powyższych objawów ocenia się w czterostopniowej skali od 0 do 3 , gdzie 0 oznacza brak zaburzenia, 1 - lekkie nasilenie objawu, 2 - mierne nasilenie, 3 - duże nasilenie, znaczną dysfunkcję głosu; na potrzeby tego badania aktorzy wyrazili zgodę na nagranie próbek głosu za pomocą dyktafonu;

6 Ze względu na przedmiot prezentowanych badań dla orientacyjnej oceny wyprofilowano tylko wyniki prawidłowe/nieprawidłowe. 
4) metodę eksperymentu - eksperyment polegał na przekazaniu każdemu $\mathrm{z}$ aktorów wykazu zasad dotyczących higieny głosu (załącznik 1) po zakończeniu pierwszego etapu badań, a po upływie trzech miesięcy powtórzenie badań w celu porównania wyników z obu etapów.

\section{Wyniki badań własnych}

\section{Charakterystyka badanej populacji}

Badana grupa liczyła 30 aktorów, w tym 15 zawodowych i 15 amatorów7. Wszyscy zajmowali się czynnie aktorstwem w różnych łódzkich teatrach i grupach aktorskich: Teatrze Pinokio, Teatrze Chorea, grupie teatralnej Roines przy Uniwersytecie Trzeciego Wieku Akademii Humanistyczno-Ekonomicznej w Łodzi lub studiowali na kierunkach aktorskich w Warszawskiej Szkole Filmowej czy Akademii Teatralnej im. Aleksandra Zelwerowicza w Warszawie. Badana grupa była zróżnicowana pod względem wieku (od 20 do 77 lat; średnia wieku to 45,3) oraz doświadczenia scenicznego (od 2 do 53 lat). $Z$ danych zawartych w metryczce ankiety wynika, że w chwili badania jeden $\mathrm{z}$ aktorów pozostawał pod opieką lekarza foniatry.

\section{Organizacja badań}

Badania bezpośrednie, mające na celu ogólną ocenę jakości głosu, były wykonywane w siedzibach wymienionych instytucji lub w miejscach pracy badanych, najczęściej w przerwach między próbami czy spektaklami. Badanie ankietowe aktorzy wykonali samodzielnie w dogodnym dla siebie miejscu i czasie. Wszystkie powyższe czynności zostały przeprowadzone od listopada 2018 roku do kwietnia 2019 roku. Podzielono je na dwa zasadnicze etapy:

1) pierwszy etap badań:

- ocena głosu aktorów przed badaniem ankietowym (z wykorzystaniem skali GRBAS oraz obserwacji),

- badanie ankietowe (kwestionariusz pierwszy),

2) drugi etap badań (po upływie około trzech miesięcy od dnia przedstawienia badanym spisu zasad prawidłowej higieny głosu):

- badanie ankietowe (kwestionariusz drugi),

- powtórna ocena jakości głosu aktorów - po badaniu ankietowym (z wykorzystaniem obserwacji oraz skali GRBAS).

7 Podziału tego dokonali sami badani w odpowiedzi na pytanie o zawód, zaznaczając odpowiedź „Aktor zawodowy”, „Inny zawód głosowy” lub „Pozostałe”. 


\section{Ocena głosu aktorów przed badaniem ankietowym}

Aby wysnuć wnioski dotyczące możliwej poprawy jakości głosu badanych (w drugim etapie: po zapoznaniu się aktorów z zasadami higieny głosu i - ewentualnie - zmianie ich zachowań w tym zakresie), należało przeprowadzić pierwszą ocenę głosu aktorów przed badaniem ankietowym.

Na podstawie obserwacji można stwierdzić, że w całej badanej populacji najczęściej, bo u 25 badanych, występowały różnego typu zaburzenia postawy. Zaburzenia koordynacji o-f-a i nieprawidłowy tor oddechowy stwierdzono u 22, natomiast motoryki artykulacyjnej u 21 osób. Nieprawidłowe wykorzystywanie rezonatorów zdiagnozowano u 20 artystów, a u 18 zaburzenia intonacji. W mowie spontanicznej występowały również zaburzenia natężenia głosu i jego wysokości (odpowiednio 19 i 18 badanych). Zaburzenie tempa mówienia odnotowano u 7 artystów.

Podczas oceny głosu aktorów w skali GRBAS, przeprowadzonej przed podaniem zasad higieny głosu, u 11 badanych („Z” - 9, „A” - 2) nie stwierdzono zaburzeń głosu ani niepokojących symptomów podczas mówienia. Łagodne lub mierne nasilenie jednej lub więcej cech patologicznych odnotowano u 19 badanych („Z” - 6, "A" - 13), natomiast u żadnego $\mathrm{z}$ aktorów nie stwierdzono znacznego nasilenia dysfunkcji głosu' ${ }^{8}$.

\section{Wyniki pierwszego badania ankietowego}

Celem pierwszego badania ankietowego była ocena świadomości i postaw aktorów względem higieny głosu, w tym uzyskanie informacji, czy, a jeśli tak, to w jaki sposób dbają o higienę głosu na co dzień. W badaniu ankietowym 4 osoby wykazały się niewielką świadomością dotyczącą zasad higieny głosu, odpowiedzi 12 osób wskazały, że nie przykładają do nich większej uwagi, natomiast 14 osób deklarowało wysoką świadomość dotyczącą zasad higieny głosu i stosowanie się do nich na co dzień (w miarę swoich możliwości).

Obszarem pracy nad głosem, w który aktorzy wyraźnie się angażują, jest wykonywanie ćwiczeń fonacyjnych i oddechowych. Jedynie 4 osoby odpowiedziały przecząco na pytanie: „Czy wykonujesz ćwiczenia usprawniające funkcjonowanie głosu, rozwijające możliwości głosowe, oddechowe?". Spośród pozostałych 26 osób 4 wykonywały takie ćwiczenia tylko samodzielnie, 14 tylko na próbach, a 8 i na próbach, i samodzielnie. Daje się zauważyć nieco większe zaangażowanie u aktorów profesjonalnych, spośród których wszyscy zadeklarowali wykonywanie ćwiczeń głosowych, podczas gdy w grupie amatorów 11 z 15 badanych ćwiczyło głos ${ }^{9}$. Nikt z grupy „Z”

$8 \mathrm{~W}$ związku z tym we wszystkich późniejszych analizach pominięto wartości na poziomie „3”, gdyż zawsze ich liczba wynosiłaby 0 .

9 Postawione pytanie nie daje odpowiedzi, jak często badani ćwiczą swój głos oraz w jaki sposób to czynią, co oczywiście ma ogromne znaczenie dla skuteczności wykonywanej pracy. Pytanie zostało tak sformułowane, aby dało się ustalić jasne kryteria oceny, co byłoby utrudnione, gdyby miało uwzględniać dodatkowo częstość, rodzaj i jakość wykonywania ćwiczeń. 
nie odpowiedział: „Nie, nie przykładam większej uwagi do mojego głosu, po prostu używam go automatycznie, jak ręki czy nogi”, natomiast w grupie amatorów tę odpowiedź wybrało 6 respondentów.

Opisany powyżej aspekt higieny głosu został, na potrzeby uporządkowania pytań w kwestionariuszu, zaliczony do działu „Ciało a głos”, obok takich kwestii, jak dbałość o sprawność fizyczną i prawidłową postawę ciała oraz zapewnienie odpowiedniej temperatury powietrza w miejscu pracy głosem. Analiza odpowiedzi na pytania z tej części wskazuje, że niemal połowa, tj. 14 badanych odpowiedziało: „Zdecydowanie tak” na pytanie: „Czy dbasz o sprawność fizyczną?”, z czego 8 osób to profesjonaliści, a 6 amatorzy. Odpowiedź: „Raczej tak” zaznaczyło 10 badanych (po 5 z każdej grupy), a 6 odpowiedziało: „Niezbyt” ( 5 z grupy „A”, 1 z „Z”). Nikt z badanych nie odpowiedział, że wcale nie dba o sprawność fizyczną.

Innym aspektem higieny głosu, na który badani zwracali dużą uwagę, było szybkie podejmowanie leczenia infekcji górnych dróg oddechowych. Jedynie 8 osób (po $4 \mathrm{w}$ obu grupach) odpowiedziało, że początkowo czeka, aż infekcja „sama przejdzie" i dopiero po kilku dniach podejmuje leczenie, pozostali badani bezzwłocznie podejmowali interwencję - we własnym zakresie lub udawali się do lekarza.

Pytanie, które miało za zadanie doprecyzować zachowanie badanych w czasie niedyspozycji, brzmiało: „Czy zmniejszasz poziom wysiłku głosowego w czasie choroby? Czy oszczędzasz wtedy swój głos?”. Odpowiedzi pokazują, że aktorzy nie zawsze łączą leczenie infekcji i ograniczenie w tym czasie wysiłku głosowego z dbaniem o głos. Tylko jedna osoba odpowiedziała, że zupełnie przerywa wysiłek głosowy w czasie infekcji - to aktor profesjonalny w czasie leczenia foniatrycznego, co na pewno nie pozostaje bez wpływu na takie właśnie zachowanie. Nieco ponad połowa badanych, czyli 16 artystów, zadeklarowała, że ogranicza wysiłek głosowy w czasie infekcji. Pozostałych 13 respondentów odpowiedziało, że nie zmniejsza wysiłku głosowego w czasie choroby górnych dróg oddechowych, a 2 zaznaczyło odpowiedź: „W ogóle nie zwracam na to uwagi”. Zaznaczona przez 11 badanych w tej grupie odpowiedź: „Nie mogę (lub nie chcę) pozwolić sobie na zmniejszenie wysiłku głosowego nawet w czasie choroby" wskazuje na świadomość dotyczącą konieczności ograniczenia wysiłku głosowego w trakcie infekcji, lecz jednocześnie dowodzi, że badani ignorują tę wiedzę lub przedkładają pracę i poczucie obowiązku nad własne zdrowie.

Niezwykle ważnym elementem higieny głosu jest odpowiednie nawodnienie organizmu. Dla zdrowej osoby dorosłej przeciętne zapotrzebowanie na wodę wynosi od 2 do 2,5 litra na dobę ${ }^{10}$, w zależności od płci, wieku, masy ciała czy rodzaju wykonywanej aktywności. Zwiększony wysiłek głosowy i fizyczny, na jaki narażony jest aktor w swojej pracy, sprawia, że jego organizm potrzebuje więcej płynów, aby

10 Podana objętość jest sumą wszystkich płynów dostarczanych do organizmu w ciągu dnia (w napojach, owocach, warzywach oraz innych pokarmach). 
narząd głosu funkcjonował sprawnie. Tylko 5 respondentów przyjmowało odpowiednią do swojego zajęcia ilość wody - więcej niż 2,5 litry dziennie, natomiast aż 12 artystów nie spełniało nawet średniej normy wyznaczonej dla osób mniej aktywnych. U 6 osób, które odpowiedziały, że spożywają mniej niż 2 litry wody dziennie, oraz u 6, które spożywają 2-2,5 litra, zaobserwowano lekkie lub mierne zaburzenia głosu (objawy to chrypka, szorstkość głosu, głos chuchający lub napięty).

W kwestionariuszu umieszczono pytanie pozornie niezwiązane z głosem: „Ile czasu zwykle mija od momentu, kiedy zjadasz ostatni posiłek, do chwili, w której kładziesz się do łóżka?”. Odpowiedzi miały wskazać, czy badani narażają się na wystąpienie refluksu żołądkowo-przełykowo-gardłowego, zwykle kojarzonego głównie z pieczeniem i bólem w klatce piersiowej, czyli tak zwaną zgagą. Wiele badań wskazuje, że choroba refluksowa może mieć negatywny wpływ nie tylko na przełyk, ale także na gardło i krtań (szczególnie w typie LPR - refluksie gardłowo-krtaniowym). Etiologia tej choroby nie jest do końca znana ${ }^{11}$, niewątpliwie jednak czynnikiem predysponującym do wystąpienia LPR i znacznie utrudniającym leczenie jest zbyt krótki odstęp między spożyciem posiłku a przyjęciem pozycji leżącej [Zub i wsp., 2018]. Prawidłowo powinien on wynosić więcej niż trzy godziny [Kawalec, Pawlas, 2013]. Przeprowadzone badanie wykazało, że 12 badanych przestrzega tej zasady. Spośród pozostałych aż 9 osób (z czego 6 to profesjonaliści) kładło się po posiłku w czasie krótszym niż dwie godziny, narażając się tym samym na takie dolegliwości, jak uczucie przeszkody w gardle, chrypka, konieczność odchrząkiwania, kaszel, uczucie pieczenia w gardle lub przełyku i inne. Co więcej, aktorzy nie stronią od popularnych używek, mających bardzo negatywny wpływ na narząd głosu - tytoniu i alkoholu. Wyniki wskazują, że amatorzy rzadziej sięgają po papierosy i alkohol niż aktorzy zawodowi.

\section{Prezentacja i analiza wyników drugiego badania ankietowego}

W drugim etapie badania zakładano eksperymentalne sprawdzenie, jaki jest stosunek artystów scenicznych do zasad prawidłowej higieny głosu, które zostały przekazane po wypełnieniu pierwszego kwestionariusza ankiety. Z przesłanym plikiem zapoznało się 28 osób, a po trzech miesiącach od jego otrzymania 26 respondentów zadeklarowało poprawę w zakresie dbałości o swój głos, przynajmniej w jednym $\mathrm{z}$ aspektów poddawanych ocenie, z czego 5 respondentów w stopniu znaczącym ${ }^{12}$. Obszary higieny głosu, w których najwięcej badanych wprowadziło zmiany, to:

1) stosowanie dodatkowych środków nawilżających narząd głosu w czasie wzmożonego wysiłku głosowego (9 ankietowanych);

11 Prawdopodobne są dwa mechanizmy powstawania pozaprzełykowych objawów choroby refluksowej: mechanizm bezpośredni (aspiracja treści refluksowej z żołądka) oraz pośredni (nieprawidłowości w przewodnictwie nerwowym) [Zub i wsp., 2018].

12 Ich odpowiedzi na pytania drugiego kwestionariusza wskazują na zwiększenie dbałości o higienę głosu w czterech, pięciu lub sześciu aspektach. 
2) ograniczenie wysiłku głosowego w czasie infekcji górnych dróg oddechowych (8 ankietowanych);

3) ograniczenie spożywania pikantnych posiłków (5 ankietowanych);

4) praca nad prawidłową postawą ciała, dbałość o odpowiednią temperaturę powietrza w miejscu pracy głosem, wykonywanie ćwiczeń oddechowych, fonacyjnych i artykulacyjnych, spożywanie posiłków i napojów o odpowiedniej temperaturze (5 ankietowanych).

Znaczna większość, czyli 25 badanych, odpowiedziała na pytania dotyczące radzenia sobie ze stresem oraz korzystania z pomocy foniatrycznej tak samo jak w pierwszym kwestionariuszu. $Z$ pozostałych 5 badanych, którzy zaznaczyli inną opcję niż poprzednio, tylko jedna osoba zadeklarowała poprawę, a cztery zaznaczyły odpowiedź: „Stres jest dla mnie sporym problemem”, co może sugerować wzrost świadomości odczuwanych emocji, w tym lęku, napięcia lub niepokoju, związanych z szeroko pojętym stresem (wszyscy w pierwszym kwestionariuszu deklarowali, że radzą sobie z nim). Odpowiedzi na pytanie: „Czy od czasu ostatniej ankiety korzystałeś z porad foniatry?” również dowodzą większej refleksyjności tych ankietowanych: jedna osoba odpowiedziała: „Tak”, natomiast pozostałe 4 osoby: „Nie, ale czuję, że taka pomoc by mi się przydała".

Każdy z badanych mógł opisać odczucia względem własnego głosu w odpowiedzi na pytanie: „Jak myślisz, czy udało Ci się coś zmienić, żeby lepiej dbać o swój głos?”. Nie wszyscy skorzystali z tej możliwości (9 osób nie udzieliło żadnej odpowiedzi), niektórzy stwierdzili, że dobrze dbają o głos i nie potrzebują nic zmieniać (11 osób). Ankietowani, którzy stwierdzili, że po trzech miesiącach lepiej dbają o głos (10 osób), wśród zmian wymieniali między innymi większą świadomość dotyczącą możliwych przyczyn zaburzeń głosu oraz ogólną poprawę komfortu pracy głosem. Zwracali oni szczególną uwagę na częstsze wietrzenie pomieszczeń, korzystanie z nawilżaczy powietrza oraz zwiększenie dbałości o odpowiednie nawodnienie organizmu, zwłaszcza w okresie wzmożonego wysiłku głosowego.

\section{Ocena głosu aktorów po wprowadzeniu zasad higieny głosu}

Po trzech miesiącach od przekazania badanym zasad higieny głosu ponowna obserwacja i ocena odsłuchowa głosu wykazały, że wraz ze wzrostem świadomości i modyfikacją zachowań jakość głosu badanych uległa poprawie. W porównaniu z wynikami z pierwszego etapu pozytywne zmiany odnotowano w zakresie postawy ciała (poprawa u 4 artystów podczas rozmowy z badającym, jednak w swobodnych rozmowach między sobą aktorzy często powracali do starych nawyków) oraz techniki mówienia (poprawa u 4 badanych) i emisji głosu (poprawa u 6 artystów). W drugim badaniu odsłuchowym niepokojące symptomy (chrypka, szorstkość głosu, głos chuchający, napięcie głosu) występowały z mniejszym natężeniem i zostały odnotowywane u mniejszej liczby badanych (16 osób: „Z” - 5, „A” - 11). Na takim samym, raczej zadowalającym poziomie pozostała siła głosu aktorów. 


\section{Omówienie wyników}

Z przeprowadzonych badań wynika, że wielu artystów scenicznych jest świadomych znaczenia higieny głosu dla jakości komunikacji ustnej. Już w pierwszym badaniu ankietowym prawie połowa respondentów (14osób) deklarowała zarówno wysoką świadomość dotyczącą zasad higieny, jak i ich przestrzeganie. Z trzydziestoosobowej grupy badanej po trzech miesiącach 28 osób poczuło potrzebę lub chociaż ciekawość dotyczącą poznania albo przypomnienia sobie zasad higieny głosu. Co więcej, aż 26 z 28 aktorów, którzy zapoznali się z przesłanym plikiem, zadeklarowało $\mathrm{w}$ drugim etapie badań zwiększenie świadomości dotyczącej pracy głosem oraz poprawę jakości głosu po zastosowaniu się do wytycznych. Uzyskane wyniki badań pozwalają też wnioskować o wysokim poziomie świadomości respondentów w kwestii zależności jakości i komfortu pracy głosem od własnego zaangażowania w trening narządów odpowiedzialnych za jego tworzenie, a według Marioli Śliwińskiej-Kowalskiej i współautorów [2003] jedną z głównych przyczyn zapadalności na choroby narządu głosu w tzw. zawodach głosowych jest brak opanowania prawidłowej techniki emisji głosu.

Obszarem pracy nad głosem, w który badani aktorzy wyraźnie się angażują, jest wykonywanie ćwiczeń fonacyjnych i oddechowych. Respondenci obu grup wskazują potrzebę usprawniania czynności fonacyjnych i oddechowych, choć daje się zauważyć nieco większe zaangażowanie u aktorów profesjonalnych, spośród których wszyscy deklarowali wykonywanie ćwiczeń, podczas gdy w grupie amatorów głos doskonaliło 11 z 15 badanych. Część badanych znalazła w sobie chęć i motywację do trwałej zmiany postaw oraz do skorygowania nieprawidłowych zachowań, co dało pozytywny efekt już po trzech miesiącach stosowania się do podstawowych zasad higieny głosu i doskonalenia techniki emisji głosu. Badania Śliwińskiej-Kowalskiej i współautorów [2002] potwierdzają, że już po dwu-, trzymiesięcznym treningu następuje poprawa parametrów głosowych oraz stanu narządu głosu.

W grupie aktorów profesjonalnych odnotowano większe zaangażowanie $\mathrm{w}$ dbałość o kondycję ciała, co może być wynikiem konieczności zachowania jej na wysokim poziomie dla utrzymania jak najwyższej jakości wykonywanej pracy scenicznej (nie tylko głosowej). Mimo deklarowanej świadomości dotyczącej higieny głosu postawy respondentów z grupy „Z” częściowo podawały w wątpliwość przestrzeganie podstawowych jej zasad na co dzień. Wśród profesjonalistów było więcej osób, które nie zachowywały wystarczająco długiego czasu między ostatnim posiłkiem a przyjęciem pozycji leżącej. Być może takie zachowanie jest efektem nieregularnego trybu życia, złego nawyku jedzenia kolacji tuż przed snem lub nieświadomości konsekwencji. Zachowanie aktorów zawodowych może też być spowodowane zdezorganizowanym trybem życia, jaki często prowadzą, nie mając wpływu na czas trwania prób czy porę granych spektakli, nierzadko kończących się późnym wieczorem lub wręcz w nocy. 
Deklarowana częściej przez profesjonalistów ekspozycja na stres (wszyscy badani w grupie „Z” zarówno w pierwszym, jak i drugim badaniu ankietowym odpowiedzieli, że odczuwają tremę przed występami), z którym nie zawsze potrafią sobie radzić, może sprzyjać sięganiu po używki, podobnie jak swego rodzaju moda - niektórzy nadal uznają alkohol czy papierosy za atrybut wyzwolonego, atrakcyjnego społecznie artysty. Wśród czynników niekorzystnie wpływających na funkcjonowanie narządu głosu Bożena Wiskirska-Woźnica i współautorzy [2004] oraz Ewa NiebudekBogusz i Ewelina Woźnicka [2011] wymieniają przede wszystkim palenie papierosów, które uszkadza transport śluzowo-rzęskowy w drogach oddechowych, co w efekcie prowadzi do przekrwienia, wysuszenia oraz stanu zapalnego błony śluzowej dróg oddechowych, powoduje też zmiany obrzękowe w przestrzeni Reinckego. Nadużywanie alkoholu nie tylko wysusza błonę śluzową dróg oddechowych (podobnie jak papierosy, mocna kawa i herbata oraz stosowanie ostrych przypraw), ale podrażnia też błonę śluzową gardła [Kubiak, Wiskirska-Woźnica, Demenko, 2006]. Z deklaracji badanych aktorów wynika, że po zapoznaniu się z zasadami higieny głosu 5 osób ograniczyło spożywanie pikantnych posiłków, a jedna $\mathrm{z}$ nich zrezygnował z palenia tytoniu.

Za pozytywne zmiany w trakcie eksperymentu należy uznać stosowanie przez większą liczbę aktorów dodatkowych środków nawilżających narząd głosu oraz większą troskę o wilgotność i temperaturę powietrza w pomieszczeniu. Z pierwszego badania ankietowego wynikało, że aktorzy nie zdawali sobie sprawy z konsekwencji i ponad połowa $\mathrm{z}$ nich nie dbała o właściwe nawilżenie gardła i krtani, a przecież zmiany w drganiach fałdów głosowych mogą wystąpić już po kilku minutach oddychania suchym powietrzem. Niedostateczne nawodnienie organizmu stanowi istotny czynnik ryzyka zaburzeń głosu nie tylko wśród aktorów, ale również w innych tzw. zawodach głosowych [Śliwińska-Kowalska i wsp., 2006; Behlau, Oliveira, 2009].

Ograniczenie wysiłku głosowego podczas infekcji górnych dróg oddechowych, które w drugim badaniu zadeklarowało 8 aktorów, wskazuje na zwiększenie świadomości oraz zmianę postaw badanych. Obciążanie głosu podczas infekcji w tzw. zawodach głosowych jest często odnotowywane nie tylko wśród artystów scenicznych, ale również wśród nauczycieli - badania wskazują, że zdecydowana większość ankietowanych pracuje głosem podczas infekcji, a zaledwie kilku unika pracy głosem w tym czasie [Kosztyła-Hojna i wsp., 2008].

Odpowiedzi udzielone przez ankietowanych $\mathrm{z}$ obu grup nie różnią się $\mathrm{w}$ aż tak dużym stopniu, jak przypuszczano. Zarówno łagodnie, jak i miernie nasilone objawy zaburzeń głosu, które wystąpiły w obu badanych grupach, wymagają dalszej specjalistycznej diagnostyki foniatryczno-logopedycznej. Większa świadomość aktorów zawodowych względem własnego głosu może wynikać zarówno z kształcenia podczas studiów, bardziej ukierunkowanej samoobserwacji, jak i z aktywnego poznawania siebie oraz swojego głosu, rozumianego nie tylko jako narzędzie pracy, ale również jako cecha osobowości i element tożsamości człowieka - w tym przypadku tożsamości aktorskiej [por. Łastik, 2014]. 


\section{Wnioski}

W badaniach część autorów potwierdza skuteczność edukacji w zakresie higieny głosu [Chan, 1994; Sapir, Mathers-Schmidt, Larson, 1996; Roy, Ryker, Bless, 2000], inni wskazują na niewielkie efekty takich działań [Broaddus-Lawrence i wsp., 2000; Timmermans i wsp., 2002; Yiu, Chan, 2003]. Przeprowadzone badania własne prowadzą do następujących wniosków:

1. Podnoszenie świadomości w zakresie higieny głosu prowokuje do bardziej krytycznej (auto)refleksji i samooceny w zakresie głosu i jego zaburzeń - przyczyn oraz objawów.

2. Artyści sceniczni są świadomi, że utrzymanie higieny narządu głosu pomaga w zapobieganiu zaburzeniom głosu oraz przeciwdziała nasilaniu się nieprawidłowości.

3. Aktorzy zawodowi mają większą świadomość własnego głosu niż amatorzy.

4. Wprowadzane w ciągu zaledwie trzech miesięcy zmiany w codziennym zachowaniu, zgodne z zasadami higieny głosu, pozytywnie wpłynęły na komfort pracy głosem.

5. W grupie aktorów profesjonalnych odnotowano z jednej strony większe zaangażowanie w dbałość o kondycję ciała oraz w ćwiczenia $\mathrm{z}$ techniki emisji głosu, z drugiej zaś częstsze sięganie po używki i zaburzony rytm dnia, co dowodzi, że świadomość dotycząca higieny głosu nie zawsze współwystępuje z właściwymi postawami i zachowaniami.

6. Osoby pracujące głosem mają potrzebę dokształcania się w celu poprawienia jego jakości, komfortu i efektywności pracy oraz lepszego dbania o zdrowie narządów odpowiedzialnych za tworzenie głosu, jednak konieczny jest bodziec, który skłoni je do podjęcia takich działań. Podczas wprowadzania zmian zgodnych z zasadami higieny oraz prawidłowej techniki emisji głosu mogą wystąpić trudności z samodyscypliną [por. Hackworth, 2007].

7. U osób pracujących głosem większa świadomość dotycząca zaburzeń głosu i zidentyfikowanie patologicznych objawów często okazuje się niewystarczająco skuteczną motywacją do skonsultowania się ze specjalistą (u którego wizyta jest postrzegana jako uciążliwa czasowo i organizacyjnie [por. Weekly i wsp., 2018]).

8. Podczas przygotowania adeptów sztuki aktorskiej do późniejszej pracy zawodowej należy kłaść większy nacisk na profilaktykę zaburzeń głosu (w zakresie wiedzy, świadomości, postaw, zachowań). W przypadku amatorów funkcję edukatora powinna przyjąć osoba prowadząca grupę teatralną, w której uczestniczą. 


\section{Załącznik 1. Podstawowe zasady higieny głosu (dla osób pracujących głosem)}

1. W miarę możliwości zadbaj o odpowiednią temperaturę i wilgotność pomieszczenia (optymalnie: temperatura: $18-21^{\circ} \mathrm{C}$ i wilgotność powietrza około $50 \%$ ).

2. Wietrz pomieszczenia często, krótko i intensywnie, ale nie wyziębiaj ich. Unikaj przeciągów. Unikaj mówienia na zimnym powietrzu.

3. Rozgrzej narząd głosowy oraz rozluźnij całe ciało przed rozpoczęciem pracy.

4. Znajdź swój własny sposób odreagowania stresu. Pamiętaj o relaksacji.

5. Wypijaj w ciągu dnia minimum 2 litry (około 8 szklanek) niegazowanej wody mineralnej, a w okresach intensywnej pracy głosowej nawet więcej. Popijaj ją często, małymi łykami.

6. Unikaj mówienia podniesionym głosem, krzyku; naucz się mówić donośnie bez nadmiernego obciążania narządu głosowego.

7. Mów wyraźniej, a nie głośniej.

8. Dostosuj natężenie głosu do pomieszczenia, w którym pracujesz. Jeśli masz możliwość, korzystaj ze sprzętu nagłaśniającego, zwłaszcza w dużych salach i przestrzeniach.

9. Rób przerwy w czasie pracy, które wykorzystasz na odpoczynek głosowy (milczenie).

10. Podczas mówienia zachowuj wyprostowaną, swobodną postawę ciała, utrzymuj głowę w linii prostej z kręgosłupem.

11. Po dłuższej pracy głosem zachowaj milczenie i pozwól zregenerować się narządowi głosowemu.

12. Oszczędzaj głos, ale nie używaj często półgłosu lub szeptu, nie stosuj też zbyt długich przerw w mówieniu.

13. Nie wysilaj narządu głosu w czasie infekcji i stanów zapalnych krtani.

14. Jeśli jesteś kobietą - nie dopuszczaj do przeciążenia aparatu głosowego na kilka dni przed i w trakcie menstruacji.

15. Unikaj czynnego i biernego palenia papierosów.

16. Ogranicz spożycie kawy, mocnej herbaty na rzecz herbat owocowych i ziołowych, wody, niezbyt gęstych, niskosłodzonych soków. Unikaj też ostrych przypraw, dań i napojów bardzo gorących lub bardzo zimnych, alkoholu (w nadmiarze), ogranicz spożycie soli.

17. Zadbaj o zdrową dietę, bogatą w witaminy, błonnik i białko.

18. Ogranicz spożycie lodów i zrezygnuj z mrożonych napojów, zwłaszcza bezpośrednio przed wysiłkiem głosowym.

19. Dbaj o higienę jamy ustnej i gardłowej, ale nie płucz gardła płynem zawierającym alkohol. Zwracaj uwagę na drożność nosa.

20. Ubieraj się stosownie do temperatury otoczenia, by uniknąć nadmiernego przegrzewania okolicy krtani. 
21. Ćwicz regularnie całe ciało; aktywność fizyczną dostosuj do możliwości oraz stanu zdrowia.

22. Nie nadwyrężaj głosu poza pracą - uważaj na głos np. podczas meczów, koncertów, spotkań ze znajomymi w hałaśliwych miejscach.

23. Zapobiegaj chorobom, zwłaszcza dróg oddechowych - dbaj o odporność organizmu.

24. Doraźnie stosuj środki wspomagające funkcjonowanie i higienę narządu głosu (środki oczyszczające, nawilżające śluzówkę jamy nosa, jamy gardłowej).

25. Obserwuj i wsłuchuj się we własny głos, poznaj jego możliwości i własne odczucia.

26. Opanuj prawidłową technikę mówienia i emisji głosu.

27. W miarę możliwości staraj się codziennie wykonać kilka ćwiczeń usprawniających funkcjonowanie narządu głosu oraz rozwijających twoje możliwości głosowe. Ćwicz swobodną artykulację i dobrą dykcję.

28. Wykonuj badania okresowe. Niepokojące objawy ze strony narządu głosu konsultuj z lekarzem foniatrą. Stosuj się do zaleceń lekarza i nie próbuj leczyć dolegliwości głosowych wyłącznie na własną rękę.

29. Jeśli pojawiają się szumy uszne, trudności ze słyszeniem lub rozróżnianiem znaczenia słów, udaj się na badanie słuchu (słabszy słuch powoduje głośniejsze mówienie).

\section{Załącznik 2. Przestrzeganie zasad prawidłowej higieny głosu wśród artystów scenicznych. Kwestionariusz I}

\section{Metryczka}

1. Imię i nazwisko: .......................................... (Potrzebne jedynie do powiązania kwestionariusza $\mathrm{z}$ wynikiem badania jakościowego Twojego głosu.)

2. Wiek:

3. Zawód, główne zajęcie:

a) Aktor zawodowy

b) Inny zawód głosowy (np. nauczyciel, śpiewak, pracownik call center i in.)

c) Pozostałe (w tym uczeń, student, emeryt)

\section{CIALO A GLOS}

1. Czy dbasz o sprawność fizyczną?

a) Zdecydowanie tak

b) Raczej tak

c) Niezbyt

d) Wcale 
2. Jak opisałbyś/-ałabyś postawę swojego ciała? (Jeśli masz taką możliwość, zanim zaznaczysz odpowiedzi, stań przed lustrem i popatrz na swoje ciało. Spróbuj nie wartościować tego, co widzisz. Patrz na siebie tak, jak patrzy lekarz na pacjenta). Zaznacz wszystkie pasujące punkty:

a) Wyprostowana, kręgosłup bez żadnych krzywizn niefizjologicznych

b) Zgarbiona (klatka piersiowa lekko wklęsła) lub inne skrzywienia kręgosłupa

c) Głowa wysunięta lekko w przód lub w tył, przekrzywiona na bok

d) Barki na jednakowej wysokości

e) Jeden z barków jest wyżej niż drugi

f) Postawa swobodna, bez niepotrzebnych napięć mięśniowych

g) Napięte mięśnie szyi, nieznacznie uniesione barki lub inne napięcia w ciele

h) Ciężar ciała rozłożony równomiernie

i) Ciężar ciała (środek ciężkości) przesunięty na bok lub w inną stronę

3. Jak odczuwasz temperaturę powietrza w miejscach, w których najczęściej pracujesz głosem? (Oczywiście jest to uwarunkowane porą roku i innymi czynnikami.)

a) Zwykle jest mi za ciepło (zbyt mocne ogrzewanie, za ciepły ubiór itd.)

b) Zwykle jest komfortowo, nie czuję przegrzania ani przechłodzenia

c) Zwykle jest mi zimno, często muszę ubierać się cieplej niż w innych miejscach, w których przebywam.

4. Czy wykonujesz ćwiczenia usprawniające funkcjonowanie głosu, rozwijające możliwości głosowe, oddechowe?

a) Tak, na próbach

b) Tak, samodzielnie

c) Tak, na próbach i samodzielnie

d) Nie

\section{NAWYKI ŻYWIENIOWE}

1. Ile płynów przyjmujesz średnio w ciągu doby? (Wszystkich, wliczając również zupy czy koktajle.)

a) Mniej niż 2 litry

b) Około 2-2,5 litra

c) Więcej niż 2,5 litra

2. Czy pijesz mocną kawę?

a) Tak, więcej niż jedną w ciągu dnia

b) Tak, jedną dziennie lub rzadziej

c) $\mathrm{Nie}$

3. Czy pijesz mocną herbatę?

a) Tak, więcej niż jedną w ciągu dnia

b) Tak, jedną dziennie lub rzadziej

c) Nie 


\section{Czy jesz pikantnie doprawione posiłki?}

a) Tak, często

b) Tak, ale rzadko

c) $\mathrm{Nie}$

5. Czy jesz gorące posiłki i pijesz gorące napoje?

a) Tak, zwykle nie czekam, aż ostygną na tyle, by nie parzyły mi ust

b) Czasami

c) Nie, jem i piję ciepłe, ale nie gorące

6. Ile czasu zwykle mija od momentu, kiedy zjadasz ostatni posiłek, do chwili, w której kładziesz się do łóżka? (Być może, ze względu na tryb życia, każdy Twój dzień wygląda inaczej - w takiej sytuacji postaraj się podać uśredniony czas. Uwaga! Jeśli kładziesz się w ciągu dnia, również to uwzględnij. Licz każde położenie się po posiłku, nie musisz wtedy spać.)

a) Mniej niż 2 godziny

b) Około 2-3 godziny

c) Więcej niż 3 godziny

7. Czy palisz papierosy? (też elektroniczne)

a) Tak, czynnie

b) Tak, biernie (wdycham dym, gdy ktoś pali blisko mnie)

c) $\mathrm{Nie}$

8. Czy pijesz alkohol?

a) Tak, często

b) Tak, czasami

c) $\mathrm{Nie}$

\section{CZYNNIKI PSYCHICZNE, EMOCJONALNE}

1. Czy obserwujesz swój głos? Czy starasz się go poznawać - jego brzmienie, skalę, możliwości i ograniczenia?

a) Zdecydowanie tak, stale pracuję nad swoim głosem

b) Tak, robię to czasami

c) Nie, nie przykładam większej uwagi do mojego głosu, po prostu używam go automatycznie, jak ręki czy nogi

2. Jak radzisz sobie ze stresem?

a) Radzę sobie dobrze, sytuacje stresowe nie są dla mnie problemem

b) Radzę sobie dość dobrze, choć zdarzają się sytuacje, w których chciałbym/-łabym umieć robić to lepiej

c) Stres jest dla mnie sporym problemem

d) Czuję, że zupełnie nie radzę sobie ze stresem

3. Czy odczuwasz tremę? Jeśli tak, jak wpływa na Twój głos?

a) Nie odczuwam tremy

b) Odczuwam tremę, ale nie zauważam, by miała jakiś wpływ na mój głos 
c) Odczuwam tremę i zauważam jej niewielki wpływ na mój głos

d) Odczuwam tremę, która znacząco wpływa na mój głos

IV. WYSIŁEK GLOSOWY, LECZENIE (Wysiłek głosowy to takie zachowania, które mogą nadwyrężyć głos - mówienie lub śpiewanie przez długi czas, w hałasie, krzyk itp.)

1. Czy dodatkowo nawilżasz narząd głosu w czasie wzmożonego wysiłku głosowego? Czy stosujesz coś więcej niż wodę, np. napar z siemienia lnianego, preparaty apteczne lub inne środki?

a) Tak

b) $\mathrm{Nie}$

c) Czasami

2. Czy zwracasz uwagę na to, by nie pić bardzo zimnych napojów i nie jeść lodów na krótko przed wysiłkiem głosowym?

a) W ogóle nie zwracam na to uwagi

b) Mam świadomość, że nie jest to wskazane, ale nie przejmuję się tym

c) Tak, staram się tego unikać

3. Co robisz, gdy zauważasz u siebie pierwsze objawy infekcji górnych dróg oddechowych?

a) Od razu staram się temu zaradzić, żeby choroba się nie rozwinęła - natychmiast udaję się do lekarza lub sam/-a próbuję się wyleczyć

b) Początkowo czekam, aż „samo przejdzie”, po kilku dniach podejmuję leczenie

c) Nie zwracam uwagi na drobne przeziębienia, zaczynam się leczyć i idę na zwolnienie dopiero, gdy choroba zaczyna mi bardzo utrudniać funkcjonowanie

4. Czy zmniejszasz poziom wysiłku głosowego w czasie choroby? Czy oszczędzasz wtedy swój głos?

a) Przerywam zupełnie wysiłek głosowy, mówię tylko wtedy, gdy jest to naprawdę konieczne

b) Ograniczam nadmierny wysiłek głosowy

c) Nie mogę (lub nie chcę) pozwolić sobie na zmniejszenie wysiłku głosowego nawet w czasie choroby

d) W ogóle nie zwracam na to uwagi

5. Czy przyjmujesz leki (stale lub doraźnie) mogące negatywnie wpływać na głos? (Jeśli nie wiesz, czy Twoje leki mają taki wpływ, poszukaj na ulotce informacji, czy lek wysusza śluzówkę, odwadnia lub osłabia koordynację ruchową.)
a) Tak
b) $\mathrm{Nie}$
6. Czy jesteś pod opieką lekarza foniatry?
a) Tak
b) Nie
c) Teraz nie, ale w przeszłości korzystałem z pomocy foniatry 


\section{Załącznik 3. Przestrzeganie zasad prawidłowej higieny głosu wśród artystów scenicznych. Kwestionariusz II}

Imię i nazwisko:

\section{INFORMACJE WSTĘPNE}

1. Otrzymałem wiadomość z załącznikiem pdf pt. „Podstawowe zasady higieny głosu"

a) Tak

b) Nie

2. Zapoznałem się z otrzymanymi zasadami

a) Tak

b) Nie

3. Jak myślisz, czy udało Ci się coś zmienić, żeby lepiej dbać o swój głos? (Może zauważyłeś/-aś już jakieś pozytywne zmiany w jego brzmieniu lub w komforcie pracy? Może coś sprawiło Ci trudność lub przyszło z łatwością? A może stwierdziłeś/-aś, że dobrze dbasz o głos i nie potrzebujesz nic zmieniać? Odpowiedz, nawet jeśli nie czytałeś/-aś pliku lub jeśli przeczytałeś/-aś, ale żadnej z zasad nie wprowadziłeś/-aś w życie.)

\section{CIAŁO A GŁOS}

1. Czy dbasz o sprawność fizyczną?

a) Zdecydowanie tak

b) Raczej tak

c) Niezbyt

d) Wcale

2. Jak opisałbyś/-ałabyś postawę swojego ciała?

a) Nie zmieniła się od poprzedniego badania (wciąż jest wyprostowana, swobodna, moje barki są na równej wysokości, a ciężar ciała rozłożony równomiernie)

b) Nie zmieniła się, chociaż pewnie powinienem/powinnam nad nią popracować (cechuje ją chociaż jedno ze stwierdzeń: zgarbiona, spięta, nierównomiernie rozłożony ciężar, barki na różnej wysokości lub uniesione itp.)

c) Pracowałem nad jej poprawą

d) Inne:

3. Jak odczuwasz temperaturę powietrza w miejscach, w których najczęściej pracujesz głosem?

a) Zwykle jest komfortowa, nie czuję przegrzania ani przechłodzenia

b) Zwykle jest mi za ciepło lub za zimno

4. Czy wykonujesz ćwiczenia usprawniające funkcjonowanie głosu, rozwijające możliwości głosowe, oddechowe?

a) Tak, na próbach i samodzielnie 
b) Tak, na próbach

c) Tak, samodzielnie

d) $\mathrm{Nie}$

\section{NAWYKI ŻYWIENIOWE}

1. Ile płynów przyjmujesz średnio w ciągu doby?
a) Mniej niż 2 litry
b) Około 2-2,5 litra
c) Więcej niż 2,5 litra

\section{Czy pijesz mocną kawę?}

a) Tak, więcej niż jedną w ciągu dnia

b) Tak, jedną dziennie lub rzadziej

c) $\mathrm{Nie}$

\section{Czy pijesz mocną herbatę?}

a) Tak, więcej niż jedną w ciągu dnia

b) Tak, jedną dziennie lub rzadziej

c) $\mathrm{Nie}$

4. Czy jesz pikantnie doprawione posiłki?

a) Tak, często

b) Tak, ale rzadko

c) $\mathrm{Nie}$

5. Czy jesz gorące posiłki i pijesz gorące napoje?

a) Tak, zwykle nie czekam, aż ostygną na tyle, żeby nie parzyły mi ust

b) Czasami

c) Nie, jem i piję ciepłe, ale nie gorące

6. Ile czasu zwykle mija od momentu, kiedy zjadasz ostatni posiłek do chwili, w której kładziesz się do łóżka? (Dla przypomnienia: postaraj się podać uśredniony czas, licz każde położenie się po posiłku, nie musisz wtedy spać).
a) Mniej niż 2 godziny
b) Około 2-3 godziny
c) Więcej niż 3 godziny

7. Czy palisz papierosy? (też elektroniczne)
a) Tak, czynnie
b) Tak, biernie
c) $\mathrm{Nie}$
8. Czy pijesz alkohol?
a) Tak, często
b) Tak, czasami
c) $\mathrm{Nie}$ 


\section{CZYNNIKI PSYCHICZNE, EMOCJONALNE}

1. Czy obserwujesz swój głos? Czy starasz się go poznawać - jego brzmienie, skalę, możliwości i ograniczenia?

a) Zdecydowanie tak, stale pracuję nad swoim głosem

b) Tak, robię to czasami

c) Nie, nie przykładam większej uwagi do mojego głosu, po prostu używam go automatycznie, jak ręki czy nogi

2. Jak radzisz sobie ze stresem?

a) Radzę sobie dobrze, sytuacje stresowe nie są dla mnie problemem

b) Radzę sobie dość dobrze, choć zdarzają się sytuacje, w których chciałbym/-łabym umieć robić to lepiej

c) Stres jest dla mnie dużym problemem

d) Czuję, że zupełnie nie radzę sobie ze stresem

3. Czy odczuwasz tremę? Jeśli tak, jak wpływa na Twój głos?

a) Nie odczuwam tremy

b) Odczuwam tremę, ale nie zauważam, by miała jakiś wpływ na mój głos

c) Odczuwam tremę i zauważam jej niewielki wpływ na mój głos

d) Odczuwam tremę, która znacząco wpływa na mój głos

\section{WYSIŁEK GŁOSOWY, LECZENIE}

1. Czy dodatkowo nawilżasz narząd głosu w czasie wzmożonego wysiłku głosowego?

a) Tak

b) Nie

c) Czasami

2. Czy zwracasz uwagę na to, by nie pić bardzo zimnych napojów i nie jeść lodów na krótko przed wysiłkiem głosowym?

a) Nie, nigdy nie zwracam na to uwagi

b) Mam świadomość, że nie jest to wskazane, ale nie przejmuję się tym

c) Tak, staram się tego unikać

3. Co robisz, gdy zauważasz u siebie pierwsze objawy infekcji górnych dróg oddechowych?

a) Od razu staram się temu zaradzić, żeby choroba się nie rozwinęła - natychmiast udaję się do lekarza lub sam/-a próbuję się wyleczyć

b) Początkowo czekam, aż „samo przejdzie”, po kilku dniach podejmuję leczenie

c) Nie zwracam uwagi na drobne przeziębienia, zaczynam się leczyć i idę na zwolnienie dopiero, gdy choroba zaczyna mi bardzo utrudniać funkcjonowanie

4. Czy zmniejszasz poziom wysiłku głosowego w czasie choroby? Czy oszczędzasz wtedy swój głos?

a) Przerywam zupełnie wysiłek głosowy, mówię tylko wtedy, gdy to naprawdę konieczne 
b) Ograniczam nadmierny wysiłek głosowy

c) Nie mogę (lub nie chcę) pozwolić sobie na zmniejszenie wysiłku głosowego nawet w czasie choroby

d) W ogóle nie zwracam na to uwagi

5. Czy teraz przyjmujesz leki mające negatywny wpływ na głos?

a) Tak

b) $\mathrm{Nie}$

6. Czy od czasu ostatniej ankiety korzystałeś z porad foniatry?

a) Tak

b) $\mathrm{Nie}$

c) Nie, ale czuję, że taka pomoc by mi się przydała.

Literatura

Behlau M., Oliveira G., 2009, Vocal hygiene for the voice professional, „Current Opinion in Otolaryngology \& Head and Neck Surgery", no. 17(3), s. 149-154.

Binkuńska E., 2012, Higiena i emisja głosu mówionego, Bydgoszcz: Wydawnictwo Uniwersytetu Kazimierza Wielkiego.

Błaszczyk J.W., 1993, Kontrola stabilności postawy ciała, „Kosmos”, nr 42(2), s. 473-486.

Broaddus-Lawrence P.L., Treole K., McCabe R.B., Allen R.L., Toppin L., 2000, The effect of preventive vocal hygiene education on the vocal hygiene habits and perceptual vocal characteristics of training singers, „Journal of Voice”, no. 14, s. 58-71.

Chan R., 1994, Does the voice improve with the vocal hygiene education? A study of some instrumental voice measures in a group of kindergarten teachers, „Journal of Voice”, no. 8, s. $279-291$.

Cieszyńska J., 2016, Zaburzenia głosu u osób śpiewających, [w:] B. Kamińska, S. Milewski (red.), Logopedia artystyczna, Gdańsk: Harmonia Universalis, s. 288-296.

Gładyszewska-Fiedoruk K., 2010, Analiza stanu środowiska wewnętrznego w wybranych przedszkolach ze szczególnym uwzględnieniem dwutlenku węgla, „Ciepłownictwo, Ogrzewnictwo, Wentylacja", nr 2, s. 28-30.

Hackworth R.S., 2007, The effect of vocal hygiene and behavior modification instruction on the self-reported vocal health habits of public school music teachers, „International Journal of Music Education", no. 25(1), s. 21-31.

Kamińska B., Milewski S. (red.), 2016, Logopedia artystyczna, Gdańsk: Harmonia Universalis.

Kawalec A., Pawlas K., 2013, Czynniki środowiskowe wpływajace na sen oraz zachowywanie higieny snu, „Problemy Higieny i Epidemiologii”, nr 94(1), s. 1-5.

Kisiel M., 2012, Emisja i higiena głosu w pracy dydaktyczno-wychowawczej nauczyciela, Dąbrowa Górnicza: Wydawnictwo Wyższej Szkoły Biznesu.

Kosztyła-Hojna B., Citko D., Milewska A., Rogowski M., 2008, Analiza występowania zaburzeń jakości głosu u pracowników dydaktycznych Uniwersytetu Medycznego w Białymstoku, „Polski Merkuriusz Lekarski”, nr 25, s. 236-239.

Kubiak Sz., Wiskirska-Woźnica B., Demenko G., 2006, Zarys higieny narządu głosu, Włocławek: Wyższa Szkoła Humanistyczno-Ekonomiczna.

Łastik A., 2014, Poznaj swój głos... twoje najważniejsze narzędzie pracy, Warszawa: Studio EMKA. 
Marody M., 1976, Sens teoretyczny a sens empiryczny pojęcia postawy. Analiza metodologiczna zasad doboru wskaźników w badaniach nad postawami, Warszawa: Państwowe Wydawnictwo Naukowe.

Niebudek-Bogusz E., Woźnicka E., 2011, Profilaktyka chorób zawodowych narządu głosu, [w:] M. Śliwińska-Kowalska (red.), Zasady orzekania o predyspozycjach zawodowych do pracy $w$ narażeniu na hałas lub nadmierny wysiłek głosowy oraz diagnostyka i profilaktyka chorób narządu stuchu i narządu głosu, Warszawa: Centrum Medyczne Kształcenia Podyplomowego, s. $157-163$.

Nowak S. (red.), 1973, Teorie postaw, Warszawa: Państwowe Wydawnictwo Naukowe.

Obrębowski A., 2008, Narząd głosu i jego znaczenie w komunikacji społecznej, Poznań: Wydawnictwo Uniwersytetu Medycznego.

Pawłowski Z., 2005, Foniatryczna diagnostyka wykonawstwa emisji głosu śpiewaczego i mówionego, Kraków: Oficyna Wydawnicza Impuls.

Pruszewicz A. (red.), 1992, Foniatria kliniczna, Warszawa: Państwowy Zakład Wydawnictw Lekarskich.

Rokitiańska M., Laskowska H., 2003, Zdrowy głos, Bydgoszcz: Akademia Bydgoska.

Roy N., Ryker K.S., Bless D.M, 2000, Vocal violence in actors; an investigation into its acoustic consequences and the effects of hygienic laryngeal release training, „Journal of Voice”, no. 14, s. $215-230$.

Sapir S., Mathers-Schmidt B., Larson G.W., 1996, Singers' and non-singers' vocal health, vocal behaviors and attitudes towards voice and singing: indirect findings from a questionnaire, „European Journal of Disorders of Communication”, no. 31, s. 193-209.

Śliwińska-Kowalska M., Fiszer M., Kotyło P., Ziatkowska E., Stępowska M., Niebudek-Bogusz E., 2002, Ocena wpływu ćwiczeń techniki emisji głosu na stan narządu głosu u uczniów kolegium nauczycielskiego, „Medycyna Pracy”, nr 53(3), s. 229-232.

Śliwińska-Kowalska M., Fiszer M., Niebudek-Bogusz E., Ziatkowska E., Kotyło P., Domańska M., 2003, Ocena skuteczności terapii głosowej w leczeniu zaburzeń głosu u nauczycieli, „Medycyna Pracy", nr 54(4), s. 319-325.

Śliwińska-Kowalska M., Niebudek-Bogusz E., Fiszer M., Łoś-Spychalska T., Kotyło P., Sznurowska-Przygocka B., Modrzewska M., 2006, The Prevalence and Risk Factors for Occupational Voice Disorders in Teachers, „Folia Phoniatrica et Logopaedica”, no. 58, s. 85-101.

Śliwińska-Kowalska M., Niebudek-Bogusz E. (red.), 2009, Rehabilitacja zawodowych zaburzeń głosu. Poradnik dla nauczycieli, Łódź: Instytut Medycyny Pracy.

Tarasiewicz B., 2006, Mówię i śpiewam świadomie, Kraków: Wydawnictwo Universitas.

Timmermans B., De Bodt M.S., Wuyts F.L., Boudewijns A., Clement G., Peeters A., Van de Heyning P.H., 2002, Poor voice quality in future elite vocal performers and professional voice users, „Journal of Voice”, no. 16, s. 372-381.

Walencik-Topiłko A., 2012, Głos jako narzędzie. Materiały do ćwiczeń emisji głosu dla osób pracujących głosem i nad głosem, Gdańsk: Wydawnictwo Harmonia.

Weekly E.M., Carroll L.M., Korovin G.S., Fleming R., 2018, A Vocal Health Survey Among Amateur and Professional Voice Users, „Journal of Voice”, no. 32(4), s. 474-478.

Wiskirska-Woźnica B., Obrębowski A., Świdziński P., Wojnowski W., Wojciechowska A., 2004, Wpływ palenia tytoniu na funkcję fonacyjna krtani, „Przegląd Lekarski”, nr 61(10), s. 1068-1070.

Wysocka M., Skoczylas A., Szkiełkowska A., Mularzuk M., 2009, Standard postępowania logopedycznego w przypadku zaburzeń głosu, „Logopedia”, nr 37, s. 243-254.

Yiu E.M., Chan R.M., 2003, Effect of hydration and vocal rest on the vocal fatigue in amateur karaoke singers, „Journal of Voice”, no. 17, s. 216-227.

Zub K., Zatoński T., Morawska-Kochman M., Szydełko U., Kręcicki T., 2018, Pozaprzełykowe manifestacje choroby refluksowej w laryngologii, „Lekarz POZ”, nr 4, s. 331-340. 


\section{Streszczenie}

Higiena głosu jest niezwykle ważna dla aktorów zawodowych i amatorów, gdyż głos jest jednym z podstawowych narzędzi, jakimi posługują się w teatrze. W niniejszym artykule przedstawiono najważniejsze zasady dotyczące higieny głosu oraz wyniki dwuetapowego badania, które miało wykazać, w jakim stopniu i w jaki sposób aktorzy uwzględniają te wytyczne w swoim życiu. Uzyskane dane potwierdziły, że stosowanie się do głównych zasad higieny głosu wpływa na jakość komunikacji w życiu codziennym oraz podczas występów na scenie.

\section{Abstract}

Vocal hygiene is extremely important for professional actors and amateurs since their voice is one of the basic tools which they use in the theatre. This article presents the most important principles regarding vocal hygiene and the results of a two-stage study showing to what extent and in what way actors take these guidelines into account in their lives. The obtained data confirmed that adherence to the main principles of vocal hygiene has an impact on the quality of communication in everyday life and during performances on the stage. 